\title{
Keefektifan Penerapan Model Pembelajaran Think Pair And Share Melalui Pendekatan Inquiry Ditinjau dari Kemandiriran Belajar Terhadap Prestasi Belajar Matematika
}

\author{
Dewi Mutia Anggraeni ${ }^{1)}$, Paridjo2), Eleonora Dwi W' \\ Jurusan Pendidikan Matematika, FKIP Universitas Pancasakti Tegal ${ }^{1,2,3)}$ \\ Gedung Dekanat FKIP Jl. Halmahera Km. 1 Kota Tegal, Kodepos 52122 Telp. (0283) \\ 357122 \\ Corresponding author's: dewimutiaanggraeni@gmail.com¹), muhparidjo@gmail.com²)

\section{Effectiveness Of The Application Of Think Pair And Share Learning Model Through Approach To Inquiry Reviewed From Self-Learning To Mathematical Learning Achievements}

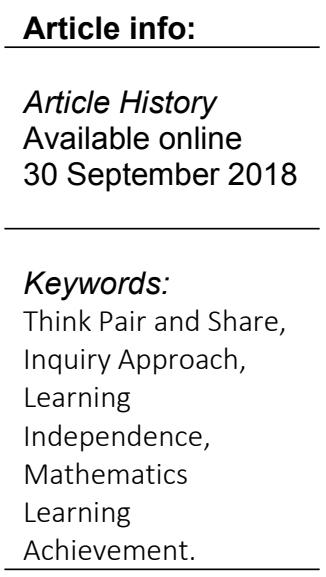

\begin{abstract}
Abstrak
Penelitian ini bertujuan : (1) Untuk mengetahui apakah ada perbedaan prestasi belajar matematika antara peserta didik yang diajar dengan menggunakan model pembelajaran Think Pair and Share melalui Pendekatan Inquiry dan model pembelajaran Ekspositori.(2) Untuk mengetahui apakah prestasi belajar matematika peserta didik yang diajar model pembelajaran Think Pair and Share melalui Pendekatan Inquiry lebih baik dari pada yang diajar menggunakan model pembelajaran Ekspositori ditinjau dari kemandirian belajar tinggi.(3) Untuk mengetahui apakah prestasi belajar matematika peserta didik yang diajar menggunakan model pembeljaran Think Pair and Share melalui Pendekatan Inquiry tidak lebih baik daripada yang diajar menggunakan model pembelajaran Ekspositori ditinjau dari kemandirian belajar rendah. Populasi dalam penelitian ini adalah peserta didik kelas VII SMP Negeri 3 Brebes tahun pelajaran 2016/2017. Pengambilan sampel menggunakan teknik cluster random sampling. Sampel yang diambil sebanyak 2 kelas eksperimen, 2 kelas kontrol, dan 1 kelas ujicoba. Teknik pengumpulan data yang digunakan adalah tes, angket, dan dokumentasi. Teknik analisis data yang digunakan dengan menetapkan taraf signifikansi $5 \%$ adalah uji Anava dengan Rancangan Acak Kelompok, uji-t satu pihak kanan, dan uji-t satu pihak kiri, yang sebelumnya telah dilakukan uji prasyarat yaitu uji normalitas dan uji homogenitas. Dari hasil penelitian dapat disimpulkan bahwa: (1) Ada perbedaan prestasi belajar matematika antara peserta didik yang diajar menggunakan model pembelajaran Think Pair and Share melalui Pendekatan Inquiry dengan model pembelajaran Ekspositori. (2) Prestasi belajar matematika peserta didik yang diajar menggunakan model pembelajaran Think Pair and Share melalui Pendekatan Inquiry lebih baik daripada yang diajar menggunakan model pembelajaran Ekspositori ditinjau dari kemandirian belajar tinggi. (3) Prestasi belajar matematika peserta didik yang diajar menggunakan model pembelajaran Think Pair and Share melalui
\end{abstract}




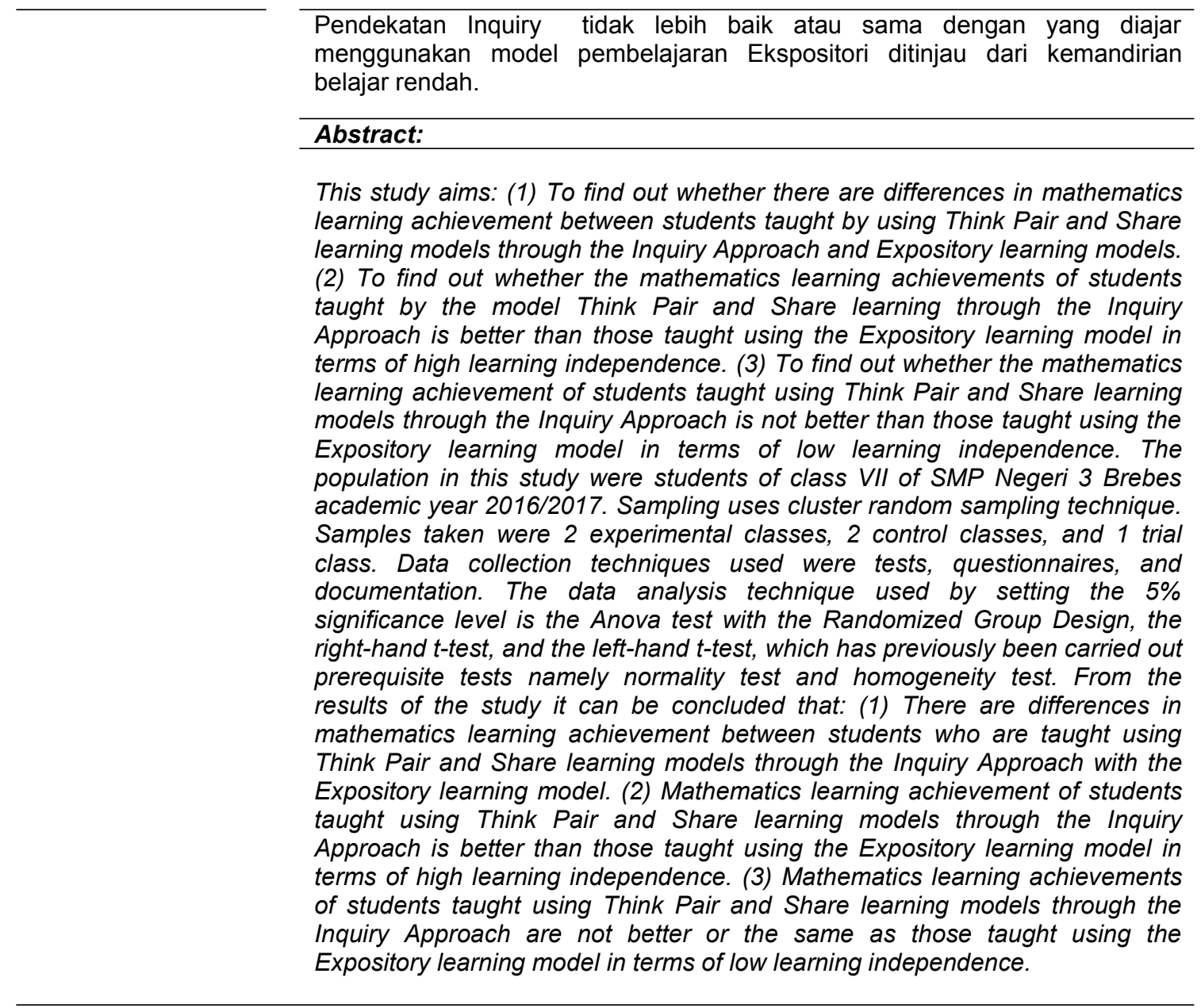

\section{PENDAHULUAN}

Pendidikan mempunyai peranan yang sangat penting untuk menjamin perkembangan dan kelangsungan kehidupan bangsa bersangkutan, sehingga untuk mempertahankan kelangsungan hidup dan mengembangkan dirinya secara terus menerus dari suatu generasi ke generasi berikutnya, Bangsa Indonesia telah menyusun suatu sistem pendidikan nasional sebagai alat dalam mencapai cita-cita dan tujuan nasional. Dengan demikian setiap warga diharapkan dapat mengikuti pendidikan pada tahap-tahap mana saja dalam kehidupannya untuk mengembangkan diri sebagai manusia Indonesia.

Pesatnya perkembangan ilmu pengetahuan dan teknologi dewasa ini tidak terlepas dari peran matematika, karena hampir semua bidang keilmuan dan teknologi membutuhkan bantuan matematika. Matematika berupa perhitungan, analisa, dan konsep ilmiah serta sebagai alat bantu yang sangat penting bagi ilmu lain. Pengetahuan tentang matematika memberikan bahasa dan teori serta memberikan pengembangan berpikir analitis, logis, dan sistematis. Matematika mendasari perkembangan teknologi modern dan mempunyai peran penting dalam berbagai disiplin ilmu serta memajukan daya pikir manusia. Karena itu perlu adanya peningkatan mutu pendidikan matematika. Oleh karenanya matematika perlu dibelajarkan kepada peserta didik sedini mungkin, sesuai dengan tingkat perkembangannya untuk membekali kemampuan berpikir logis, analitis, sistematis, kritis dan kreatif. 
Berdasarkan hasil observasi awal dengan guru matematika kelas VII SMP Negeri 3 Brebes, ditemukan beberapa permasalahan dalam pembelajaran yang dilakukan, diantaranya adalah proses pembelajaran menggunakan model yang kurang bervariasi, masih rendahnya prestasi belajar matematika, dan kurang tertariknya dengan pelajaran matematika dikarenakan peserta didik bosan dengan sistem pembelajaran yang hanya itu-itu saja. Peneliti berpikir perlu diterapkan suatu model pembelajaran yang dapat membuat peserta didik mempunyai keinginan mengikuti pembelajaran, sehingga diharapkan dapat meningkatkan prestasi belajar matematika peserta didik karena peserta didik mampu menyukai dan memahami materi yang diajarkan guru.

Model pembelajaran merupakan salah satu komponen dalam pembelajaran yang mempunyai arti kegiatan-kegiatan guru selama proses pembelajaran berlangsung. Semakin tepat memilih model pembelajaran diharapkan makin efektif dalam mencapai tujuan. Oleh karena itu guru perlu memperhatikan dalam memilih model pembelajaran. Model pembelajaran Think pair and Share merupakan suatu model pembelajaran yang dapat mengaktifkan seluruh peserta didik selama proses pembelajaran dan memberikan kesempatan untuk bekerja sama antar peserta didik yang mempunyai kemampuan heterogen. Model ini cocok diterapkan untuk pembelajaran matematika karena peserta didik akan lebih cenderung aktif, berpikir secara mandiri, serta mampu bekerja sama pada teman-temannya. Namun tidaklah sempurna jika suatu model pembelajaran tidak di sokong oleh pendekatan yang tepat, oleh karena itu agar penelitian ini lebih efektif maka peneliti akan berusaha mengkolaborasikan antara model pembelajaran Think Pair and Share melalui Pendekatan Inquiry. Inquiry adalah suatu pendekatan yang melibatkan secara maksimal seluruh kemampuan siswa untuk mencari dan menyelidiki secara sistematis, kritis, logis, analitis, sehingga mereka dapat merumuskan sendiri dengan penuh percaya diri.Seorang guru harus bisa membaca karakteristik maasing-masing peserta didiknya. Kemandirian adalah termasuk faktor interal yang menyebabkan rendahnya prestasi belajar matematika. Untuk itu, guru dituntut untuk dapat menumbuhkan rasa kemandirian peserta didik agar dapat mengungkapkan pendapatnya selama proses pembelajaran.

Rumusan masalah yang akan dijadikan fokus dalam penelitian ini adalah (1) Apakah ada perbedaan prestasi belajar matematika antara peserta didik yang diajar dengan menggunakan model pembelajaran Think Pair and Share melalui Pendekatan Inquiry dan model pembelajaran Ekspositori? (2) Apakah prestasi belajar matematika peserta didik yang diajar model pembelajaran Think Pair and Share melalui Pendekatan Inquiry lebih baik dari pada yang diajar menggunakan model pembelajaran Ekspositori ditinjau dari kemandirian belajar tinggi? (3) Apakah prestasi belajar matematika peserta didik yang diajar menggunakan model pembeljaran Think Pair and Share melalui Pendekatan Inquiri tidak lebih baik daripada yang diajar menggunakan model pembelajaran Ekspositori ditinjau dari kemandirian belajar rendah?

Melalui penelitian ini guru diharapkan dapat mengembangkan variasi model pembelajaran yang tepat dalam kegiatan pembelajaran sehingga pembelajaran tidak monoton dan peserta didik tidak bosan dalam mengikuti kegiatan pembelajaran.

\section{METODE}

Penelitian ini dilaksanakan pada peserta didik kelas VII semester genap Tahun Pelajaran 2016/2017 di SMP Negeri 3 Brebes dengan jenis penelitian eksperimen 
dimana terjadi hubungan sebab akibat antara kelas eksperimen dan kelas kontrol, yaitu dengan tujuan untuk mengetahui ada tidaknya perbedaan prestasi belajar siswa yang diajar menggunakan model pembelajaran Think Pair and Share melalui Pendekatan Inquiry dengan siswa yang diajar dengan menggunkan model pembelajaran Ekspositori ditinjau dari kemandirian bealajar siswa. Subyek penelitian ini adalah peserta didik kelas VII G SMP Negeri 3 Brebes yang berjumlah 33 orang, terdiri dari 17 peserta didik perempuan dan 16 peserta didik laki-laki.

Teknik pengumpulan data yang digunkan dalam penelitian meliputi 3 teknik yaitu teknik dokumentasi, teknik angket, dan teknik tes. Instrumen yang digunakan dalam penelitian ini adalah tes prestasi belajar dan angket kemandirian belajar. Teknik analisis instrumen tes pada penelitian ini menggunakan : (1) Uji validitas, penggunaan validitas tes prestasi menggunakan rumus Point biserial karena bentuk instrumennya pilihan ganda, (2) Uji reliabilitas menggunakan rumus KR-20, (3) Daya pembeda suatu item, ditentukan dari proporsi tes kelompok atas yang dapat menjawab dengan benar butir item yang bersangkutan dikurangi proporsi tes kelompok bawah yang dapat menjawab dengan benar butir item tersebut, (4) Tingkat kesukaran, ditentukan atas banyaknya peserta didik yang menjawab benar butir soal dibanding jumlah seluruh peserta didik yang mengikuti tes. Sedangkan teknik analisis instrumen angket pada penelitian ini menggunakan : (1) Uji validitas, penggunaan validitas angket kemandirian belajar menggunakan rumus Product Moment, (2) Uji reliabilitas menggunakan rumus alpha.

Uji hipotesis menggunakan uji Anava dengan Rancangan Acak Kelompok (RAK). Uji prasyarat meliputi uji normalitas menggunakan metode Liliefors dan uji homogenitas menggunakan metode Bartlet.

\section{Jenis Penelitian}

Penelitian ini menggunakan pendekatan kuantitatif, karena penelitian ini datanya berupa angka-angka dan dianalisis menggunakan uji statistik, serta meneliti suatu populasi dimana sampel diambil secara random dan pengumpulan datanya menggunakan instrumen.

\section{Waktu dan Tempat Penelitian}

Penelitian ini dilakukan pada tanggal

7 Januari s/d 6 Maret 2017. Dengan tempat pelaksanaan di SMP Negeri 3 Brebes .

\section{Target/Subjek Penelitian}

Populasi yang digunakan adalah seluruh peserta didik kelas VII SMP Negeri 3 Brebes. Dengan teknik pengambilan sampel Cluster Random Sampling atau pengambilan sampel secara acak. Sehingga diperoleh sampel 5 kelas yaitu 2 kelas untuk kelas eksperimen, 2 kelas untuk kelas kontrol, dan 1 kelas untuk uji coba.

\section{Prosedur Penelitian}

Penelitian ini berjenis penelitian eksperimen atau mencari perlakuan terhadap sampel. Prosedur penelitian ini diawali dengan observasi awal - mengidentifikasi masalah - membuat rumusan masalah dari identifikasi yang ada - pengumpulan data - analisis data - dan memberikan kesimpulan. 


\section{Data, Intrumen, dan Teknik Pengumpulan Data}

Data yang digunakan pada penelitian ini adalah data yang berskala nominal dan rasio.Sedangkan Instrumen yang digunakan dalam penelitian ini adalah instrumen angket dan instrumen tes. Untuk pengumpulan data peneliti menggunakan teknik dokumentasi yaitu metode pengumpulan data berupa nama-nama, daftar nilai penilaian akhir semester 1 , peneliti juga menggunakan teknik tes untuk mengetahui nilai prestasi belajar matematika peserta didik dan menggunakan teknik angket untuk mengetahui kemandirian belajar peserta didik.

\section{Teknik Analisis Data}

Penelitian ini menggunakan uji prasyarat berupa uji normalitas dan homogenitas serta menggunakan uji Anava dengan RAK, uji-t satu pihak kanan, dan uji-t satu pihak kiri.

\section{HASIL DAN PEMBAHASAN}

Prestasi belajar peserta didik dapat dideskripsikan sebagai berikut.

\section{Kelas Eksperimen}

Berdasarkan data diatas dapat dilihat untuk kelas eksperimen mempunyai nilai rataan sebesar 72,059 dengan jangkauannya 50 , serta mempunyai median 70 , modus 70 , dan standar deviasi 13,136.

Tabel 1. Deskripsi Prestasi Belajar Kelas Eksperimen

\begin{tabular}{clc}
\hline No. & \multicolumn{1}{c}{ Distribusi Data } & Nilai Kelas Eksperimen \\
\hline 1. & Mean & 72,059 \\
2. & Median & 70 \\
3. & Modus & 70 \\
4. & Std. Deviasi & 13,136 \\
5. & Nilai Tertinggi & 95 \\
6. & Nilai Terendah & 45 \\
7. & Jangkauan & 50 \\
\hline
\end{tabular}

\section{Kelas Kontrol}

Berdasarkan data diatas untuk kelas kontrol mempunyai nilai rataan sebesar 65,797 , median sebesar 65 , modus sebesar 70 , standar deviasi sebesar 12,994 , serta jangkauan sebesar 60

Tabel 2. Deskripsi Prestasi Belajar Kelas Kontrol

\begin{tabular}{clc}
\hline No. & \multicolumn{1}{c}{ Distribusi Data } & Nilai Kelas Kontrol \\
\hline 1. & Mean & 65,797 \\
2. & Median & 65 \\
3. & Modus & 70 \\
4. & Std. Deviasi & 12,994 \\
5. & Nilai Tertinggi & 95 \\
6. & Nilai Terendah & 35 \\
7. & Jangkauan & 60 \\
\hline
\end{tabular}


3. Prestasi belajar matematika ditinjau dari kemandirian belajar

Tabel 3. Deskripsi data prestasi belajar matematika ditinjau dari kemandirian belajar

\begin{tabular}{llcccc}
\hline \multirow{2}{*}{ No } & \multicolumn{4}{c}{ Model Pembelajaran } \\
\cline { 2 - 5 } & \multicolumn{2}{c}{ TPS melalui pendekatan Inquiry } & \multicolumn{2}{c}{ Ekspositori } \\
\cline { 2 - 5 } & $\begin{array}{c}\text { Kemandirian } \\
\text { belajar tinggi }\end{array}$ & $\begin{array}{c}\text { Kemandirian } \\
\text { belajar rendah }\end{array}$ & $\begin{array}{c}\text { kemandirian } \\
\text { belajar tinggi }\end{array}$ & $\begin{array}{c}\text { Kemandirian } \\
\text { belajar rendah }\end{array}$ \\
\hline 1 Mean & 81,389 & 62,500 & 75,588 & 61,143 \\
2 & Median & 80 & 60 & 75 & 60 \\
3 & Nilai Tertinggi & 95 & 90 & 95 & 95 \\
4 & Nilai Terendah & 70 & 45 & 65 & 35 \\
5 & Jangkauan & 25 & 45 & 30 & 60 \\
6 & Modus & 85 & 65 & 70 & 60 \\
7 & Variansi & 62,302 & 109,677 & 63,280 & 201,597 \\
8 & Std. Deviasi & 7,893 & 10,473 & 7,955 & 14,198 \\
9 & Koef. Variansi & 0,097 & 0,168 & 0,105 & 0,232 \\
\hline
\end{tabular}

Berdasarkan tabel diatas dapat disimpulkan bahwa rata-rata/mean pada pembelajaran Think Pair and Share melalui Pendekatan Inquiry ditinjau dari kemandirian belajar lebih tinggi daripada lainnya yaitu 81,389. Dengan median sebesar 70 maka Think Pair and Share melalui Pendekatan Inquiry ditinjau dari kemandirian belajar tinggi mempunyai median paling tinggi. Nilai yang tertinggi dan terendah pada model pembelajaran Think Pair and Share melalui Pendekatan Inquiry ditinjau dari kemandirian belajar tinggi yaitu 95 dengan nilai tertinggi dan 70 dengan nilai terendah. Untuk standar deviasi model pembelajaran Think Pair and Share melalui Pendekatan Inquiry ditinjaun dari kemandirian belajar tinggi sebesar 7,893 dan variansi sebesar 62,302 .

Berdasarkan hasil penelitian yang dilakukan di SMP Negeri 3 Brebes pada peserta didik kelas VII semester genap tahun pelajaran 2016/2017 pokok bahasan aritmatika sosial menunjukan bahwa prestasi belajar peserta didik yang diajar menggunakan model pembelajaran Think Pair and Share melalui pendekatan Inquiry menunjukan adanya perbedaan prestasi belajar matematika antara peserta didik yang diajar menggunakan model pembelajaran Think Pair and Share melalui Pendekatan Inquiry dengan peserta didik yang menggunakan model pembelajaran Ekspositori, serta adanya perbedaan prestasi belajar matematika antara peserta didik dengan kemandirian belajar tinggi dan peserta didik dengan kemandirian belajar rendah. Hal ini dapat dibuktikan pada perhitungan Rancangan Acak Kelompok (RAK).

Adanya perbedaan prestasi belajar matematika antara peserta didik yang diajar menggunakan model pembelajaran Think Pair and Share melalui Pendekatan Inquiry dengan peserta didik yang diajar menggunakan model pembelajaran Ekspositori, hal ini dikarenakan pada kelas eksperimen diberikan pmbelajaran dengan model pembelajaran Think Pair and Share melalui Pendekatan Inquiry. Model pembelajaran Think Pair and Share melalui Pendekatan Inquiry merupakan hal baru bagi peserta didik dan dapat menciptakan suasana untuk mengembangkan kemampuan berfikir dan berargumentasi dari peserta didik dalam kegiatan belajar mengajar. Pembelajaran dengan model pembelajaran Think Pair and Share melalui Pendekatan Inquiry dapat dilakukan dalam kelompok kecil, peserta didik akan terlatih berfikir secara mandiri dan 
bertukar pendapat dengan temannya untuk mendapatkan kesepakatan dalam pemecahan masalah kemudian peserta didik dapat menyampaikan hasil pemikirannya kepada peserta didik yang lain. ( Nurhadi,2014:120)

Dalam penelitian ini, faktor dari dalam peserta didik juga diperhatikan. Kemandirian belajar sebagai salah satu dasar mengembangkan potensi yang dimiliki peserta didik menjadi tinjauan dalam penelitian ini. Kemandirian berkenaan dengan tugas dan ketrampilan bagaimana mengerjakan sesuatu atau bagaimana mengelola sesuatu. Namun kemandirian juga mencakup kemapuan menyendiri dan memikirkan sesuatu dengan pikiran mereka sendiri. ( Eti Nurhayati,2016:138)

Berdasarkan hasil pengujian dengan menggunakan uji t satu pihak kanan, jika ditinjau dari kemandirian belajar tinggi didapatkan bahwa prestasi belajar matematika peserta didik yang diajar menggunakan model pembelajaran Think Pair and Share melalui Pendekatan Inquiry lebih baik dari pada peserta didik yang diajar menggunakan model pembelajaran Ekspositori. Hal ini juga ditunjukan dengan nilai rata-rata prestasi belajar matematika peserta didik yang menggunakan model pembelajaran Think Pair and Share melalui Pendekatan Inquiry mencapai 81,389 sedangkan nilai rata-rata yang diajar menggunakan model pembelajaran Ekspositori hanya mencapai 75,558 .

Selain itu berdaasarkan pengujian dengan menggunakan uji t satu pihak kiri jika ditinjau dari kemandirian belajar rendah didapat bahwa prestasi belajar matematika peserta didik yang diajar menggunakan model pembelajaran Think Pair and Share melalui Pendekatan Inquiry lebih baik atau sama dengan peserta didik yang diajar dengan menggunakan model pembelajaran Ekspositori. Hal ini juga ditunjukan dengan nilai rata-rata prestasi belajar matematika peserta didik yang menggunakan model pembelajaran Think Pair and Share melalui Pendekatan Inquiry mencapai 62,500 sedangkan nilai rata-rata yang diajar menggunakan model pembelajaran Ekspositori mencapai 61,143 .

Berkaitan dengan hasil penelitian, baik ditinjau dari kemandirian belajar tinggi maupun kemandirian belajar rendah maka model pembelajaran Think Pair and Share melalui Pendekatan Inquiry dapat diterapkan. Hal ini diperkuat dengan penelitian yang dilakukan oleh Cucu Cahyati (2014) dengan judul " Keefektifan Model Pembelajaran Think Pair and Share Ditinjau dari Kepercayaan Diri Terhadap Prestasi Belajar Matematika" menyimpulkan bahwa model pembelajaran Think Pair and Share banyak diterapkan dibandingan dengan model pembelajaran Ekspositori. Kemudian pada penelitian yang telah dilakukan oleh Novi Ros Santi (2013) dengan judul "Keefektifan Model Pembelajaran Kooperatif Tipe Think Pair And Share Untuk Meningkatkan Hasil Belajar Siswa Pada Pembelajaran Matematika Materi Operasi Hitung Campuran Bilangan Bulat " menyimpulkan bahwa model pembelajaran Think Pair and Share lebih efektif digunakan daripada model pembelajaran konvensional karena pada model pembelajaran Think Pair and Share dapat meningkatkan hasil belajar siswa. Sedangkan menurut penelitian Indah Kumalasari (2014) dengan judul " Keefektifan Penerapan Think Pair And Share berdasarkan Motivasi Belajar Peserta Didik Terhadap Prestasi Belajar Matematika " menyimpulkan bahwa menggunakan model pembelajaran Think Pair and Share menunjukan bahwa peserta didik terlatih mempunyai motivasi belajar yang tinggi, sehingga model pembelajaran Think Pair and Share efektif diterapkan pada pembelajaran disekolah. 
Pembelajaran dengan menggunakan model pembelajaran Think Paid and Share tidak lepas dari kekurangan. Model pembelajaran Think Pair and Share melalui Pendekatan Inquiri memerlukan waktu dan tenaga lebih banyak dalam penerapanannya. Namun hal demikian dapat diatasi jika guru dapat menguasai materi dan langkah-langkah pembelajarannya dengan baik sehingga akan tercapai.

\section{SIMPULAN DAN SARAN}

\section{Simpulan}

Berdasarkan hasil penelitian dapat disimpulkan bahwa (1) Ada perbedaan prestasi belajar matematika peserta didik yang diajar menggunakan model pembelajaran Think Pair and Share melalui Pendekatan Inquiry dan yang diajar dengan menggunakan model pembelajaran ekspositori. (2) Prestasi belajar matematika peserta didik yang diajar dengan menggunakan model pembelajaran Think Pair and Share melalui Pendekatan Inquiry lebih baik daripada peserta didik yang diajar menggunakan model pembelajaran ekspositori ditinjau dari kemandirian belajar tinggi. (3) Prestasi belajar matematika peserta didik yang diajar dengan menggunakan model pembelajaran Think Pair and Share melalui Pendekatan Inquiry lebih baik atau sama dengan peserta didik yang diajar menggunakan model pembelajaran ekspositori ditinjau dari kemandirian belajar rendah.

\section{Saran}

Berdasarkan hasil pembahasan dan simpulan, saran yang perlu disampaikan adalah sebagai berikut :

1. Bagi Guru

a) Hendaknya para guru, khususnya guru matematika menggunakan model dan metode pembelajaran yang bervariasi (tidak monoton) salah satunya dengan penerapan model pembelajaran Think Pair and Share melalui Pendekatan Inquiry,sehingga dapat meningkatkan semangat dan prestasi belajar peserta didik.

b) Guru matematika hendaknya selain mengajar materi matematika juga harus memberikan dorongan kepada peserta didik untuk lebih percaya dan yakin dengan kemampuan yang dimiliki dalam dirinya sendiri untuk meraih prestasi yang baik, maksimal serta dapat belajar mandiri.

c) Dalam proses pembelajaran matematika diharapkan guru dapat memotivasi peserta didik dengan lebih melibatkan peserta didik dalam pembelajaran.

2. Bagi Sekolah

Diharapkan dapat menjadi bahan masukan dalam upaya meningkatkan kualitas di sekolah yang mengarah pada pencapaian prestasi belajar matematika yang optimal dengan memperhatikan kemandirian peserta didik serta sumber - sumber pembelajaran yang ada perlu dikembangkan sehingga pengetahuan peserta didik juga bisa berkembang.

3. Bagi Peneliti Lain

Perlu dilakukan lebih lanjut dengan metode, model, ataupun pendekatan yang lain terhadap materi pokok yang berbeda pula agar metode tersebut dapat berkembang dan lebih bermanfaat untuk kegiatan pembelajaran. Selain itu juga dengan 
memperhatikan faktor - faktor lain yang berhubungan dengan prestasi belajar matematika.

\section{DAFTAR PUSTAKA}

Arikunto, Suharsimi. 2013. Dasar - Dasar Evaluasi Pendidikan. Jakarta: Bumi Aksara.

Arikunto, Suharsismi. 2013. Prosedur Penelitian: Suatu Pendekatan Praktik. Jakarta: Rineka Cipta.

Cahyati, Cucu. 2015. Keefektifan Model Pembelajaran Kooperatif tipe Think Pair and Share ditinjau dari Kepercayaan diri Terhadap Prestasi Belajar Matematika Pada Materi Pokok Statistika (Suatu Penelitian pada kelas $X$ semester 2 SMK Muhammadiyah Larangan Kabupaten Brebes Tahun Pelajar 2014/2015). Tegal: Bahan Penerbitan Universitas Pancasakti Tegal.

Gaspersz, Vincent. 2005. Teknik Analisis Dalam Penelitian Percobaan. Bandung: Tarsito.

Hidayati Kana, dkk. 2010. "Pengembangan Instrumen Kemandirian Belajar Mahasiswa". Jurnal FMIPA UNY. ejournal.uny.ac.id

Kumalasari, Indah. 2014. Keefektifan Penerapan Think Pair And Share berdasarkan Motivasi Belajar Peserta Didik Terhadap Prestasi Belajar Matematika. e-journal Edutech Universitas Ganesha Jurusan Teknologi Pendidikan (Vol: 2 No: 3 Tahun 2014)

Majid, Abdul. 2012. Strategi Pembelajaran. Bandung: Pemuda Rosdakarya.

Nurhayati, Eti. 2011. Psikologi Pendidikan Inovatif. Yogyakarta: Pustaka Belajar.

Parker, Deborah. 2006. Menumbuhkan Kemandirian dan Harga diri Anak. Jakarta: Prestasi Pustakarya.

Rusman. 2012. Model - Model Pembelajaran Mengembangkan Profesionalisme Guru. Jakarta: Raja Grafindo Persada.

Santi, Novi Ros. 2013. Keefektifan Model Pembelajaran Kooperatif Tipe Think Pair And Share Untuk Meningkatkan Hasil Belajar Siswa Pada Pembelajaran Matematika

Materi Operasi Hitung Campuran Bilangan Bulat. e-journal Edutech Universitas Pendidikan Indonesia Jurusan Pendidikan Matematika (Vol: 2 No:1 Tahun 2013)

Setiawati, Sulis. 2014. Keefektifan Penerapan Problem Based Learning Berdasarkan Kemandirian Belajar Peserta didik Terhadap Prestasi Belajar Matematika( Suatu Penelitian Pada Kelas VII Semester II SMP 2 Adiwerna Kabupaten Tegal Tahun Pelajarn 2013/2014 pada Materi Kubus dan Balok). Tegal: Badan Penerbitan Universitas Pancasakti Tegal.

Shoimin, Aris. 2014. 68 Model Pembelajaran Inovatif Dalam Kurikulum 2013. Yogyakarta: Ar-Ruzz Media.

Sudjana. 2005. Metoda Statistika. Bandung: Tarsito

Slameto. 2010. Belajar dan Faktor - Faktor yang Mempengaruhinya. Jakarta: PT Rineka Cipta.

Sugiyono. 2015. Metode Penelitian Pendidikan. Bandung: Alfabeta.

Susongko, Purwo. 2013. Penelitian Hasil Belajar. Tidak Diterbitkan. Tegal: Universitas Pancasakti Tegal.

Susongko, Purwo. 2014. Pengantar Metodologi Penelitian Pendidikan. Tidak Diterbitkan. Tegal: Universitas Pancasakti Tegal. 